\title{
METODYKA ZARZADZANIA SYTUACYJNEGO BEZPIECZEŃSTWEM INFRASTRUKTURY KRYTYCZNEJ PAŃSTWA
}

DOI: 10.33141/po.2019.11.05

\section{Michał Wiśniewski}

\section{Wprowadzenie}

C iągły rozwój cywilizacyjny prowadzi do uzależniania się społeczeństwa od szeroko rozumianej infrastruktury. Sprawia to, że obywatele przestają być samowystarczalni w wielu obszarach życia codziennego. Część tej infrastruktury to tzw. infrastruktura krytyczna (dalej IK). Definiowana jest jako systemy oraz wchodzące w ich skład powiązane ze sobą funkcjonalnie obiekty, w tym obiekty budowlane, urządzenia, instalacje, usługi kluczowe dla bezpieczeństwa państwa i jego obywateli oraz służące zapewnieniu funkcjonowania organów administracji publicznej, a także instytucji i przedsiębiorców (Dz.U. z 2019 r., poz. 1398, art. 3, pkt 2).

Sprawność IK jest rozumiana jako realizowanie wyznaczonych zadań (funkcjonalności) na założonym poziomie. Warunkuje ona poczucie bezpieczeństwa obywateli, suwerenność państwa. Dodatkowo wpływa na tempo wzrostu gospodarczego i funkcjonowanie administracji publicznej. Ograniczenie sprawności IK w wyniku wystąpienia zagrożeń może skutkować: stratami ekonomicznymi, skażeniem środowiska naturalnego oraz zagrożeniem dla zdrowia i życia ludności (FEMA, 2017). Minimalizacja negatywnych skutków związanych z materializacją zagrożeń $\mathrm{w}$ celu wyeliminowania podatności IK na zagrożenia wymaga zastosowania mechanizmów prewencyjnych. Natomiast $\mathrm{w}$ przypadku ich materializacji wymaga planów ciągłości działania. Postępowanie podmiotu odpowiedzialnego za ochronę IK uzależnia wartość ryzyka utraty sprawności IK poniżej założonego poziomu. Poziom ryzyka wynika m.in. z podatności zasobów na zagrożenia, prawdopodobieństwa ich wystąpienia, skuteczności stosowanych zabezpieczeń oraz różnicy między założonym minimalnym poziomem realizacji wyznaczonych działań a rzeczywistym poziomem dostępności funkcjonalności. Wartości czynników wpływających na poziom ryzyka są różne dla każdej IK, a ich stan w konkretnym momencie określa sytuację IK.

Ochrona IK to działania zmierzające do zapewnienia funkcjonalności, ciągłości działań i integralności IK. Stosuje się ją w celu zapobiegania zagrożeniom, ryzykom lub słabym punktom oraz ograniczenia i neutralizacji ich skutków oraz szybkiego odtworzenia tej infrastruktury na wypadek awarii, ataków oraz innych zdarzeń zakłócających jej prawidłowe funkcjonowanie (Dz.U. z 2019 r., poz. 1398, art. 3, pkt 3). Ochrona IK jest realizowana w ramach procesu zarządzania kryzysowego i planowania cywilnego.
Warunkiem skuteczności ochrony IK jest sprawny mechanizm wymiany informacji dotyczących zagrożeń, na które podatna jest IK (Lidwa, 2015, s. 165-176). Do grupy podmiotów odpowiedzialnych za ochronę IK należą operatorzy IK, reprezentujący jedenaście systemów IK (Dz.U. z 2019 r., poz. 1398, art. 3, pkt 2) oraz jednostki administracji publicznej.

Stosowanie procedur ochrony IK, będących elementem procesu zarządzania kryzysowego, właściwych dla jednostek administracji publicznej, utrudnia operatorom IK osiąganie zaplanowanego wyniku finansowego. Wykorzystanie metod i technik związanych z zarządzaniem ryzykiem operacyjnym stosowanych $\mathrm{w}$ organizacjach biznesowych również nie przystaje do specyfiki funkcjonowania obiektów IK. Operatorzy IK muszą uwzględniać zaplanowany wynik finansowy przedsiębiorstwa, ale muszą również zapewnić wymaganą przez społeczeństwo sprawność IK. Sytuacja ta wskazuje na nowy rodzaj problemu w naukach o zarządzaniu, w którym skuteczność działania przedsiębiorstwa komercyjnego ma wyższy priorytet niż jego efektywność. Wpisuje się to w problematykę logistyki społecznej (Szołtysek, 2014). Jego rozwiązanie wymaga adaptacji metod i technik stosowanych w organizacjach biznesowych, tak aby umożliwiły one zdefiniowanie problemu decyzyjnego. Po czym następować powinien dobór zabezpieczeń dla rozpatrywanej IK pozwalających utrzymać zakładany poziom sprawności.

Ze względu na to celem autora jest opracowanie dedykowanej metodyki zarządzania sytuacyjnego bezpieczeństwem IK (ZS-BIK). Postawiony cel wskazuje na dwa pytania badawcze:

- Jakie etapy postępowania powinna zawierać metodyka ZS-BIK?

- Jakie elementy musi zawierać charakterystyka IK, aby zapewnić możliwość stonowania metodyki ZS-BIK niezależnie od systemu IK oraz rodzaju podmiotu odpowiedzialnego za ochronę IK?

\section{Metoda badawcza}

$\mathbf{R}$ ealizacja celu badawczego została podzielona na cztery etapy (tab. 1).

Badania nad literaturą z obszaru zarządzania bezpieczeństwem IK pozwoliły na rozpoznanie barier utrudniających współdziałanie podmiotów odpowiedzialnych 
Tabela 1. Program realizacji badań

\begin{tabular}{|l|l|l|}
\hline \multicolumn{1}{|c|}{ Etap badania } & \multicolumn{1}{|c|}{ Metody badawcze } & \multicolumn{1}{c|}{ Wynik etapu } \\
\hline $\begin{array}{l}\text { Analiza problematyki zarządzania } \\
\text { bezpieczeństwem IK }\end{array}$ & $\begin{array}{l}\text { Badania literaturowe } \\
\text { Analiza źródeł pierwotnych }\end{array}$ & $\begin{array}{l}\text { Określenie etapów metodyki ZS-BIK } \\
\text { Wskazanie dobrych praktyk z obszaru zarządzania bezpieczeństwem IK }\end{array}$ \\
\hline $\begin{array}{l}\text { Określenie składowych } \\
\text { charakterystyki IK }\end{array}$ & $\begin{array}{l}\text { Badania literaturowe } \\
\text { Analiza źródeł pierwotnych } \\
\text { Action research }\end{array}$ & Sformułowanie modelu sytuacji IK \\
\hline $\begin{array}{l}\text { Potwierdzenie analityczne } \\
\text { i eksperymentalne składowych } \\
\text { metodyki ZS-BIK }\end{array}$ & $\begin{array}{l}\text { Action research } \\
\text { Modelowanie } \\
\text { Eksperymenty obliczeniowe }\end{array}$ & $\begin{array}{l}\text { Opracowanie wytycznych realizacji elementów metodyki ZS-BIK } \\
\text { Opracowanie procedury realizacji metodyki ZS-BIK }\end{array}$ \\
\hline $\begin{array}{l}\text { Weryfikacja metodyki ZS-BIK } \\
\text { z wykorzystaniem danych } \\
\text { zbliżonych do rzeczywistych }\end{array}$ & $\begin{array}{l}\text { Action research } \\
\text { Eksperymenty obliczeniowe }\end{array}$ & $\begin{array}{l}\text { Potwierdzenie przydatności metodyki zarządzania bezpieczeństwem IK dla } \\
\text { podmiotów odpowiedzialnych za bezpieczeństwo IK }\end{array}$ \\
\hline
\end{tabular}

Źródto: opracowanie wtasne

za ochronę IK, rozbieżności stosowanych definicji infrastruktury krytycznej oraz ochrony IK, a także brak standardu charakterystyki IK.

Analiza porównawcza źródeł pierwotnych - aktów normatywnych, strategii, programów, norm oraz metodyk oceny ryzyka na rzecz zarządzania kryzysowego pozwoliła na ustalenie wzorcowych etapów metodyki ZS-BIK. Przeprowadzona synteza aktów formalnoprawnych z obszaru zarządzania kryzysowego oraz planowania cywilnego, uwzględniająca przepisy dotyczące Unijnego Mechanizmu Ochrony Ludności, pozwoliła na wskazanie podstawowego zbioru danych, które muszą być zgromadzone w celu wykonania charakterystyki IK.

Współzależności elementów metodyki ZS-BIK zaprojektowano za pomocą metody modelowania. Dzięki temu dane wejściowe jednego etapu metodyki stanowią dane wejściowe dla innego. Weryfikacja użyteczności opracowanej metodyki została przeprowadzona na podstawie eksperymentów obliczeniowych bazujących na danych charakteryzujących rafinerię PKN ORLEN S.A. pozyskanych z Planu Zarządzania Kryzysowego powiatu płockiego (Powiat-plock.pl, 2015).

Proces badawczy na różnych etapach był uzupełniany metodą action research polegającą na przedstawianiu wyników badań $\mathrm{w}$ ramach paneli eksperckich organizowanych na potrzeby projektu badawczego pt. „Metodyka oceny ryzyka na potrzeby systemu zarządzania kryzysowego RP”. W roli ekspertów występowali pracownicy Rządowego Centrum Bezpieczeństwa.

\section{Metodyka zarządzania sytuacyjnego bezpieczeństwem infrastruktury krytycznej}

$\mathrm{U}$ miejętność identyfikowania i przewidywania zagrożeń dla jednostek IK oraz wskazywania, jak postępować w przypadku materializacji zagrożenia, ma duże znaczenie praktyczne. Dlatego obecnie jest przedmiotem wielu inicjatyw badawczych dotyczących:

- wpływu IK na bezpieczeństwo w obszarze rozwoju gospodarczego, suwerenności państwa, wzrostu stan- dardu życia ludności (Pursiainen, 2018, s. 635-637), - wzajemnego wpływu systemów IK (Bloomfield i in., 2017, s. 198-217),

- ryzyka zależnego (Pescaroli, Kelman, 2017, s. 56-67),

- metod z obszaru nauk o zarządzaniu, które można adaptować do problematyki zarządzania bezpieczeństwem IK (Johansen, Tien, 2018),

- wymiany informacji o podatnościach na zagrożenia (Häyhtiö, Zaerens, 2017, s. 45-47),

- ustalania progu bezpieczeństwa ${ }^{1}$ dla IK (Hatton i in.. 2018, s. 59-61).

Stopień zaawansowania prac badawczych w wymienionych obszarach jest zróżnicowany. Prace dotyczą wydzielonych obszarów związanych z procesem zarządzania bezpieczeństwem IK. Daje się również zaobserwować brak propozycji kompleksowego rozwiązania, pozwalającego wskazać zbiór zabezpieczeń na podstawie zagrożeń, na które podatna jest rozpatrywana IK. Nieliczne prace dotyczące zarządzania bezpieczeństwem IK wskazują jedynie na potrzebę opracowania dedykowanego rozwiązania, określając jego ramową postać (Hofreiter, Zvakova, 2016; Häyhtiö, Zaerens, 2017). Z tego powodu brak dedykowanej metodyki zarządzania bezpieczeństwem IK został zidentyfikowany jako luka badawcza.

Zadania wykonywane na rzecz ochrony IK są w wielu krajach określone $\mathrm{w}$ metodykach oceny ryzyka na potrzeby zarządzania kryzysowego. Metodyki dostarczają wiedzy na temat etapów procesu oraz stanowią źródło możliwych do zastosowania metod pracy podmiotów odpowiedzialnych za ochronę IK. Z tego powodu przeprowadzono analizę metodyki stosowanej w Polsce (Kosieradzka, Zawiła-Niedźwiecki, 2017) i metodyk krajów, które są uznane za wiodące $\mathrm{w}$ tym obszarze, takich jak metodyka: niemiecka (Bbk.bund.de, 2011), szwedzka (Msb.se, 2012), kanadyjska (Publicsafety.gc.ca, 2013), USA (FEMA, 1997), irlandzka (Mem.ie, 2010), holenderska (Preventionweb.net, 2009). Kryterium wyboru metodyk zostało zbudowane na podstawie ilości sytuacji kryzysowych ${ }^{2}$, które występowały w ww. krajach oraz eksperckiej oceny dojrzałości rozwiązań metodycznych. 


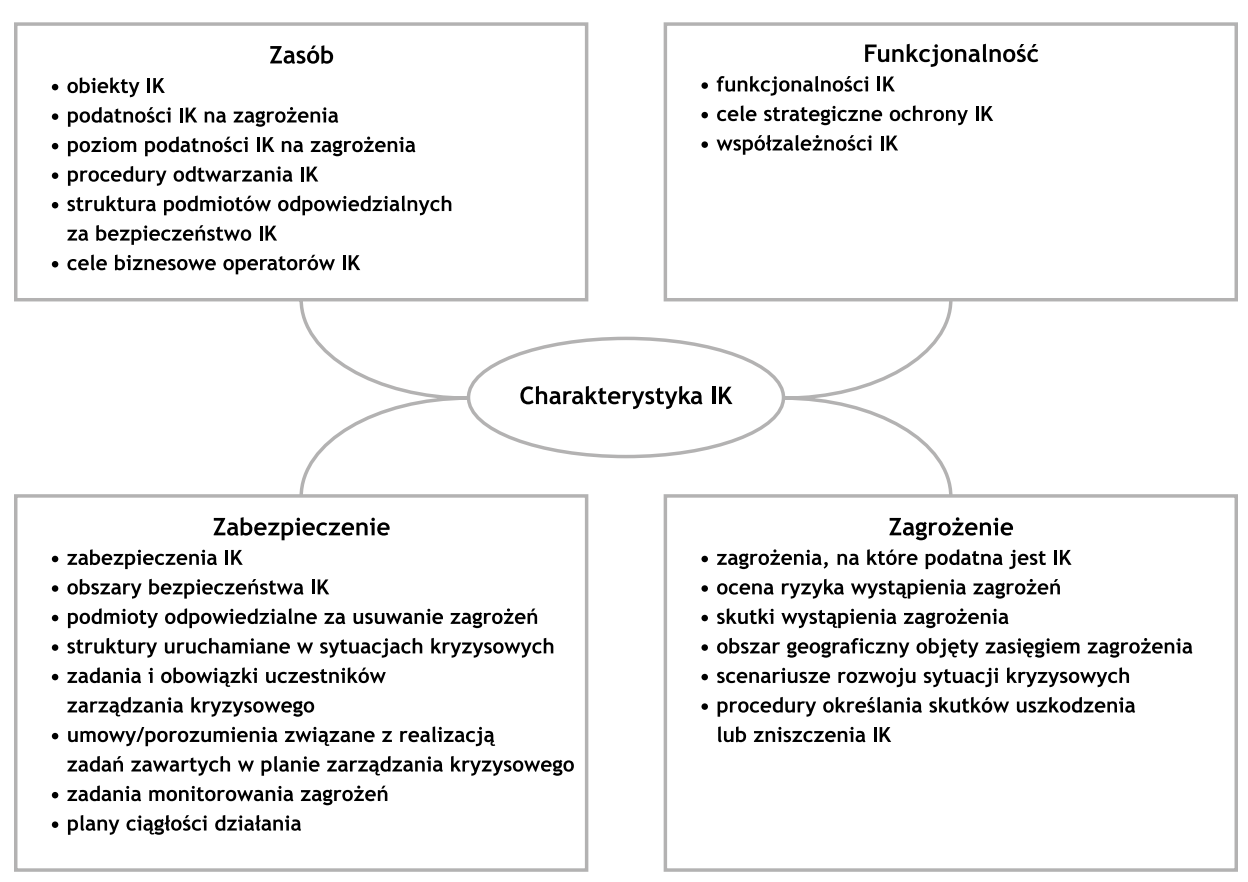

Rys. 1. Kategorie danych charakteryzujące obiekt IK wg obowiązujących uwarunkowań formalnoprawnych Źródto: opracowanie własne na podstawie: Wiśniewski, Ostrowska, 2016, s. 118-119

Wzorcem dla wszystkich wymienionych metodyk jest norma PN-EN ISO 31000:2012 Zarządzanie ryzykiem - zasady i wytyczne, która zakłada realizację procesu oceny ryzyka w trzech etapach: ustalenie kontekstu, ocena ryzyka (identyfikacja, analiza i ewaluacja) oraz decyzja o postępowaniu z ryzykiem.

Z przeprowadzonej analizy wynika, że niemal wszystkie metodyki rozpoczynają się od etapu ustalenia kontekstu. W nim rozpoznawane są zasoby podatne na zagrożenia, dla których ma być wykonana ocena ryzyka. Wyjątkiem od tej reguły są metodyka holenderska, której pierwszym etapem jest opracowanie scenariuszy zdarzeń kryzysowych, oraz szwedzka, która jest rozpoczynana od określenia obszarów odpowiedzialności i przyjęcia metody analizy ryzyka. Podobne rozwiązanie stosowane jest $\mathrm{w}$ polskiej zaawansowanej metodyce oceny ryzyka w publicznym zarządzaniu kryzysowym. W tym przypadku pierwszy moduł zakłada organizację pracy zespołu oceny ryzyka. Należy podkreślić, że metodyka szwedzka przewiduje również dodatkowy etap, niewystępujący w normie PN-EN ISO 31000:2012. Dotyczy on dokonania oceny podatności zasobów na zagrożenia.

Wszystkie analizowane metodyki zakładają realizację składowych procesu oceny ryzyka rekomendowanego przez normę PN-EN ISO 31000:2012, tzn. analizę i szacowanie ryzyka. Etapem kończącym metodyki oceny ryzyka na potrzeby zarzadzania kryzysowego jest wskazanie decyzji dotyczącej postępowania z ryzykiem. Decyzja jest podejmowana na podstawie uzyskanych wyników etapu oceny ryzyka i dotyczy doboru adekwatnych zabezpieczeń eliminujących lub ograniczających ryzyko.

Analiza siedmiu metodyk oceny ryzyka na potrzeby zarządzania kryzysowego z obszaru całego świata pozwoliła na rozpoznanie realizowanych etapów oraz dobrych praktyk związanych z zarządzaniem bezpieczeństwem IK. Wskazuje również na brak jednolitego standardu postępowania w obszarze zarządzania bezpieczeństwem IK. Dzieje się tak, mimo że wszystkie metodyki odwołują się do elementów normy PN-EN ISO 31000:2012. Brak standardu może wynikać $\mathrm{z}$ tego, że rozpatrywane metodyki odnoszą się do procesu zarządzania kryzysowego a nie bezpośrednio do procesu zarządzania bezpieczeństwem IK. Traktowanie procesu zarządzania bezpieczeństwem IK jako składowej procesu zarządzania kryzysowego jest światowym trendem. Ze względu na to nie przykłada się należytej wagi do opracowania standardu charakterystyki IK.

Przeprowadzona synteza aktów formalnoprawnych z obszaru zarządzania kryzysowego oraz planowania cywilnego, uwzględniająca przepisy polskie oraz Unii Europejskiej, pozwoliła na wskazanie czterech zbiorów danych. Charakteryzują one każdą IK niezależnie od jej przynależności do systemu IK (rys. 1). Wyniki analizy uwarunkowań formalnoprawnych ochrony IK szczegółowo przedstawiono $\mathrm{w}$ artykule M. Wiśniewskiego i T. Ostrowskiej (2016).

$\mathrm{Na}$ podstawie wyników analizy uwarunkowań formalnoprawnych regulujących ochronę IK (rys. 1) ustalono, że każdy obiekt tego typu stanowi sumę zasobów (V) umożliwiających realizację zobowiązań operatora IK, tzw. funkcjonalności $(\Phi)$. Ponadto na charakterystykę obiektu składają się zbiór zagrożeń (Z), na które IK jest podatna, oraz zbiór stosowanych zabezpieczeń (M).

Zagrożenia, które się zmaterializują, mogą wzbudzać ${ }^{3}$ inne zagrożenia, np. awaria techniczna może ograniczyć funkcjonalność IK i jednocześnie wywołać pożar, powodujący dalsze zniszczenia. Stąd charakterystykę IK należy uzupełnić o zbiór $(\mathrm{H})$, dostarczający wiedzy o zależności zagrożeń. 
Tabela 2. Opis etapów metodyki ZS-BIK

\begin{tabular}{|c|c|c|c|}
\hline Nazwa etapu & \multicolumn{3}{|c|}{ Powołanie zespołu } \\
\hline Cel etapu & Stosowane narzędzia & Dane wejściowe & Dane wyjściowe \\
\hline $\begin{array}{l}\text { Wskazanie składu osobowego } \\
\text { zespołu analitycznego } \\
\text { odpowiedzialnego za } \\
\text { bezpieczeństwo IK }\end{array}$ & $\begin{array}{l}\text { Model sytuacji IK } \\
\text { Matryca kompetencji }\end{array}$ & $\begin{array}{l}\text { Charakterystyka IK } \\
\text { Wykaz interesariuszy IK }\end{array}$ & $\begin{array}{l}\text { Skład personalny zespołu } \\
\text { analitycznego }\end{array}$ \\
\hline Postępowanie & \multicolumn{3}{|c|}{$\begin{array}{l}\text { - } \text { analiza interesariuszy rozpatrywanej IK i dobór członków zespołu } \\
\text { - weryfikacja matrycy kompetencji zespołu analitycznego }\end{array}$} \\
\hline Nazwa etapu & \multicolumn{3}{|c|}{ Określenie progu bezpieczeństwa } \\
\hline Cel etapu & Stosowane narzędzia & Dane wejściowe & Dane wyjściowe \\
\hline $\begin{array}{l}\text { Deklaratywne przyjęcie poziomów } \\
\text { funkcjonalności gwarantujących } \\
\text { realizację zadań rozpatrywanej IK }\end{array}$ & Model sytuacji IK & $\begin{array}{l}\text { Wykaz funkcjonalności } \\
\text { rozpatrywanej IK }\end{array}$ & $\begin{array}{l}\text { Wykaz funkcjonalności } \\
\text { rozpatrywanej IK z określonymi } \\
\text { progami bezpieczeństwa }\end{array}$ \\
\hline Postępowanie & \multicolumn{3}{|c|}{$\begin{array}{l}\text { - przyjęcie wykazu funkcjonalności IK wynikającego z modelu sytuacji IK } \\
\text { - określenie progu bezpieczeństwa dla każdej funkcjonalności IK } \\
\text { - zapisanie przyjętego progu bezpieczeństwa w modelu sytuacji IK }\end{array}$} \\
\hline Nazwa etapu & \multicolumn{3}{|c|}{ Odwzorowanie charakterystyki IK } \\
\hline Cel etapu & Stosowane narzędzia & Dane wejściowe & Dane wyjściowe \\
\hline $\begin{array}{l}\text { Odwzorowanie charakterystyki } \\
\text { rozpatrywanej IK }\end{array}$ & Model sytuacji IK & $\begin{array}{l}\text { Dane dotyczące: funkcjonalności } \\
\text { IK, zasobów niezbędnych do } \\
\text { realizacji funkcjonalności, } \\
\text { podatności zasobów na } \\
\text { zagrożenia, stosowanych } \\
\text { zabezpieczeń }\end{array}$ & $\begin{array}{l}\text { Charakterystyka sytuacji } \\
\text { rozpatrywanej IK }\end{array}$ \\
\hline Postępowanie & \multicolumn{3}{|c|}{$\begin{array}{l}\text { - określenie zbioru V rozpatrywanych IK } \\
\text { - określenie zbioru } \Phi \text { funkcjonalności dla każdego elementu zbioru V } \\
\text { - określenie zbioru Z zagrożeń, na które podatne są elementy zbioru V } \\
\text { - określenie zbioru H zależności występujących między elementami zbioru Z } \\
\text { - określenie zbioru M zabezpieczeń dla każdego elementu zbioru Z } \\
\text { - określenie zbioru G zależności występujących między elementami zbioru V }\end{array}$} \\
\hline Nazwa etapu & \multicolumn{3}{|c|}{ Szacowanie ryzyka } \\
\hline Cel etapu & Stosowane narzędzia & Dane wejściowe & Dane wyjściowe \\
\hline $\begin{array}{l}\text { Oszacowanie ryzyka utraty } \\
\text { funkcjonalności IK }\end{array}$ & Metoda szacowania ryzyka & $\begin{array}{l}\text { Model sytuacji IK } \\
\text { Zbiór zabezpieczeń wynikający } \\
\text { z rozwiązania problemu } \\
\text { decyzyjnego }\end{array}$ & $\begin{array}{l}\text { Poziom ryzyka utraty } \\
\text { funkcjonalności uwzględniający } \\
\text { zabezpieczenia }\end{array}$ \\
\hline Postępowanie & \multicolumn{3}{|c|}{$\begin{array}{l}\text { - określenie wartości parametrów ryzyka na podstawie modelu sytuacji IK } \\
\text { - obliczanie wartości ryzyka utraty rozpatrywanej funkcjonalności IK } \\
\text { - prognoza rozpatrywanej funkcjonalności w kolejnym okresie } \\
\text { - podjęcie decyzji o postępowaniu z zagrożeniami }\end{array}$} \\
\hline Nazwa etapu & \multicolumn{3}{|c|}{ Wygenerowanie scenariuszy zdarzeń niekorzystnych (SZN) } \\
\hline Cel etapu & Stosowane narzędzia & Dane wejściowe & Dane wyjściowe \\
\hline $\begin{array}{l}\text { Rozpoznanie możliwych } \\
\text { scenariuszy zdarzeń } \\
\text { niekorzystnych }\end{array}$ & Metoda generowania SZN & $\begin{array}{l}\text { Modele sytuacji rozpatrywanych } \\
\text { IK }\end{array}$ & $\begin{array}{l}\text { Charakterystyka SPIK } \\
\text { Wykaz SZN }\end{array}$ \\
\hline Postępowanie & \multicolumn{3}{|c|}{$\begin{array}{l}\text { - opracowanie SPIK, na bazie danych zawartych w modelach sytuacji IK } \\
\text { - przygotowanie wykazu SZN }\end{array}$} \\
\hline
\end{tabular}




\begin{tabular}{|c|c|c|c|}
\hline Nazwa etapu & \multicolumn{3}{|c|}{ Sformułowanie problemu decyzyjnego } \\
\hline Cel etapu & Stosowane narzędzia & Dane wejściowe & Dane wyjściowe \\
\hline $\begin{array}{l}\text { Opracowanie wykazu } \\
\text { dopuszczalnych } \\
\text { decyzji gwarantujących } \\
\text { osiaggnięcie wymaganego } \\
\text { progu bezpieczeństwa } \\
\text { dla rozpatrywanych } \\
\text { funkcjonalności IK }\end{array}$ & $\begin{array}{l}\text { Metoda formułowania problemu } \\
\text { decyzyjnego }\end{array}$ & $\begin{array}{l}\text { Modele sytuacji rozpatrywanych } \\
\text { IK } \\
\text { Wykaz rozpatrywanych SZN }\end{array}$ & $\begin{array}{l}\text { Wykaz dopuszczalnych decyzji } \\
\text { możliwych do zastosowania } \\
\text { w reakcji na rozpoznane } \\
\text { zagrożenia }\end{array}$ \\
\hline Postępowanie & \multicolumn{3}{|c|}{$\begin{array}{l}\text { - zbudowanie modelu problemu decyzyjnego } \\
\text { - wygenerowanie zbioru dopuszczalnych decyzji niezawierających par elementarnych decyzji znajdujących } \\
\text { się w relacji sprzeczności } \\
\text { - dokonanie wyboru i podjęcie decyzji } \\
\text { - analiza skutków podjętej decyzji }\end{array}$} \\
\hline Nazwa etapu & \multicolumn{3}{|c|}{ Wdrożenie zabezpieczeń } \\
\hline Cel etapu & Stosowane narzędzia & Dane wejściowe & Dane wyjściowe \\
\hline Rekomendacja zabezpieczeń & Model sytuacji IK & $\begin{array}{l}\text { Model sytuacji rozpatrywanej } \\
\text { IK nieuwzględniający nowych } \\
\text { zabezpieczeń }\end{array}$ & $\begin{array}{l}\text { Model sytuacji rozpatrywanej } \\
\text { IK uwzględniający nowe } \\
\text { zabezpieczenia }\end{array}$ \\
\hline Postępowanie & \multicolumn{3}{|c|}{$\begin{array}{l}\text { - rekomendacja zabezpieczeń operatorowi IK } \\
\text { - uzupełnienie charakterystyki rozpatrywanej IK o dane dotyczące wdrożonych zabezpieczeń }\end{array}$} \\
\hline
\end{tabular}

Źródło: opracowanie własne

Między samymi obiektami IK również występują zależności. Dostępność funkcjonalności jednej IK warunkuje możliwość realizacji funkcjonalności przez inną $\mathrm{IK}^{4}$. Utrata lub ograniczenie funkcjonalności tworzy warunki sprzyjające zagrożeniom, na które podatne są inne IK.

Stąd sytuacja IK jest definiowana jako aktualnie obowiązujący stan IK określany w obszarze zasobów, funkcjonalności, zagrożeń oraz zabezpieczeń, uwzględniający zależność rozpatrywanej IK z powiązanymi IK (Wiśniewski, 2019, s. 151). Na podstawie powyższego rozumowania sformułowano model sytuacji IK:

$$
<\mathrm{V}, \Phi, \mathrm{Z}, \mathrm{H}, \mathrm{M}, \mathrm{G}, \mathrm{T}>
$$

gdzie:

$\mathrm{V}$ - rozpatrywana IK,

$\Phi$ - zbiór funkcjonalności IK,

Z - zbiór zagrożeń, na które podatna jest IK,

$\mathrm{H}$ - zbiór zależności między zagrożeniami,

M - zbiór modeli zabezpieczeń IK,

G - zbiór zależności rozpatrywanej IK z innymi IK,

$\mathrm{T}$ - zbiór sygnatur czasu, w których określano stan IK.

Sformułowanie modelu sytuacji IK pozwala zdefiniować zarządzanie sytuacyjne bezpieczeństwem IK jako zespół działań realizowanych w obszarze funkcji zarządzania. Są one uzależnione od sytuacji IK i są niezbędne do osiągnięcia wymaganego progu bezpieczeństwa. Narzędziem zarządzania sytuacyjnego jest metodyka ZS-BIK, którą ilustruje tabela 2.

\section{Weryfikacja metodyki zarządzania sytuacyjnego bezpieczeństwem infrastruktury krytycznej}

tudium przypadku obrazujące zastosowanie metodyki ZS-BIK wykorzystuje dane charakteryzujące rafinerię PKN ORLEN S.A (Powiat-plock.pl, 2015, s. 20-21). Opisywany przypadek prezentuje wykonanie wybranych etapów metodyki ZS-BIK: odwzorowania charakterystyki IK, szacowania ryzyka, sformułowania problemu decyzyjnego i wdrożenia zabezpieczeń.

Do głównych obszarów działalności rafinerii PKN ORLEN S.A. (V1) należą: $\Phi_{1,1}$ - przerób ropy naftowej oraz wytwarzanie produktów i półproduktów ropopochodnych (rafineryjnych i petrochemicznych), $\Phi_{1,2}-$ magazynowanie, składowanie i przechowywanie ropy naftowej i paliw płynnych oraz tworzenie i utrzymywanie zapasów paliw, $\Phi_{1,3}-$ wytwarzanie, przesyłanie i obrót energią cieplną i elektryczną.

$\mathrm{Z}$ uwagi na prowadzone procesy technologiczne na terenie rafinerii PKN ORLEN S.A. istnieje możliwość powstania: $Z_{1,1}$ - pożaru, $Z_{1,2}$ - wybuchu, $Z_{1,3}$ - skażenia środowiska.

Operator rafinerii PKN ORLEN S.A. w odpowiedzi na rozpoznane zagrożenia wprowadził następujące zabezpieczenia: $M_{1,1,1}$ - zakładowa straż pożarna, $M_{1,1,2}$ - służba ochrony zakładu (ORLEN Ochrona sp. $\mathrm{z}$ o.o.), $\mathrm{M}_{1,2,1}-\mathrm{za}$ kładowa służba medyczna (ORLEN Medica sp. z o.o.), $\mathrm{M}_{1,3,1}$ - monitorowanie stanu środowiska.

Charakterystykę rozpatrywanej IK według modelu sytuacji IK przedstawia w tabela 3. 
Tabela 3. Syntetyczny zapis sytuacji rafinerii PKN ORLEN S.A.

\begin{tabular}{|c|c|c|c|c|c|c|c|c|c|}
\hline \multirow{3}{*}{ IK } & \multicolumn{2}{|c|}{ Funkcjonalności } & \multicolumn{6}{|c|}{ Zagrożenia } & \multirow{3}{*}{$\begin{array}{c}\text { Podatność } \\
\text { na } \\
\text { zagrożenie }\end{array}$} \\
\hline & \multirow[b]{2}{*}{ Symbol } & \multirow[b]{2}{*}{ Wartość } & \multirow[b]{2}{*}{ Symbol } & \multirow{2}{*}{$\begin{array}{l}\text { Wzbudzane } \\
\text { zagrożenie }\end{array}$} & \multirow{2}{*}{$\begin{array}{l}\text { Prawdopo- } \\
\text { dobieństwo }\end{array}$} & \multirow{2}{*}{$\begin{array}{l}\text { Ograniczenie } \\
\text { funkcjonalności } \\
\text { IK }\end{array}$} & \multicolumn{2}{|c|}{ Zabezpieczenia } & \\
\hline & & & & & & & Symbol & $\begin{array}{l}\text { Obniżenie } \\
\text { podatności }\end{array}$ & \\
\hline \multirow{4}{*}{$\mathrm{V}_{1}$} & \multirow[b]{2}{*}{$\Phi_{1,1}$} & \multirow[b]{2}{*}{$93 \%$} & \multirow[b]{2}{*}{$Z_{1,1}$} & \multirow{2}{*}{$\begin{array}{l}\text { skażenia } \\
\text { środowiska, } \\
\text { wybuch }\end{array}$} & \multirow[b]{2}{*}{0,7} & \multirow{2}{*}{$\begin{array}{l}-47 \%\left(\Phi_{1,1}\right) \\
-37 \%\left(\Phi_{1,2}\right) \\
-13 \%\left(\Phi_{1,3}\right)\end{array}$} & $M_{1,1,1}$ & 0,46 & \multirow[b]{2}{*}{0,88} \\
\hline & & & & & & & $M_{1,1,2}$ & 0,31 & \\
\hline & $\Phi_{1,2}$ & $93 \%$ & $Z_{1,2}$ & pożar & 0,56 & $\begin{array}{l}-42 \%\left(\Phi_{1,1}\right) \\
-39 \%\left(\Phi_{1,2}\right) \\
-46 \%\left(\Phi_{1,3}\right)\end{array}$ & $M_{1,2,1}$ & 0,16 & 0,81 \\
\hline & $\Phi_{1,3}$ & $93 \%$ & $Z_{1,3}$ & - & 0,81 & $\begin{array}{l}-9 \%\left(\Phi_{1,1}\right) \\
-9 \%\left(\Phi_{1,3}\right)\end{array}$ & $M_{1,3,1}$ & 0,16 & 0,31 \\
\hline
\end{tabular}

Źródło: opracowanie wtasne

Tabela 4. Ryzyko utraty funkcjonalności dla rozpatrywanych IK w czasie $t_{0}$

\begin{tabular}{|c|c|c|c|c|c|c|c|c|}
\hline IK & Zagrożenie & $\begin{array}{l}\text { Prawdopo- } \\
\text { dobieństwo }\end{array}$ & \multicolumn{2}{|c|}{ Skutek } & $\begin{array}{l}\text { Podat- } \\
\text { ność }\end{array}$ & $\begin{array}{l}\text { Zabezpie- } \\
\text { czenie }\end{array}$ & $\begin{array}{c}\text { Ryzyko } \\
\text { inherentne }\end{array}$ & $\begin{array}{l}\text { Ryzyko } \\
\text { rezydualne }\end{array}$ \\
\hline $\mathbf{V}_{a}$ & $\mathrm{Z}_{\mathrm{a}, \mathrm{B}}$ & $\mathbf{P}$ & $\Phi_{a, v}$ & $\Delta \Phi_{a, r}$ & $U_{a, B}$ & $M_{a, B}$ & $\mathbf{R}^{\mathbf{i}}$ & $\mathbf{R}^{r}$ \\
\hline \multirow{8}{*}{$V_{1}$} & \multirow{3}{*}{$Z_{1,1}$} & \multirow{3}{*}{0,7} & $\Phi_{1,1}$ & $47 \%$ & \multirow{3}{*}{0,88} & \multirow{3}{*}{0,77} & $28,95 \%$ & $3,62 \%$ \\
\hline & & & $\Phi_{1,2}$ & $37 \%$ & & & $22,79 \%$ & $2,85 \%$ \\
\hline & & & $\Phi_{1,3}$ & $13 \%$ & & & $8,01 \%$ & $1,00 \%$ \\
\hline & \multirow{3}{*}{$Z_{1,2}$} & \multirow{3}{*}{0,56} & $\Phi_{1,1}$ & $42 \%$ & \multirow{3}{*}{0,81} & \multirow{3}{*}{0,16} & $19,05 \%$ & $15,29 \%$ \\
\hline & & & $\Phi_{1,2}$ & $39 \%$ & & & $17,69 \%$ & $14,20 \%$ \\
\hline & & & $\Phi_{1,3}$ & $46 \%$ & & & $20,87 \%$ & $16,74 \%$ \\
\hline & \multirow{2}{*}{$Z_{1,3}$} & \multirow{2}{*}{0,81} & $\Phi_{1,1}$ & $9 \%$ & \multirow{2}{*}{0,31} & \multirow{2}{*}{0,16} & $2,26 \%$ & $1,09 \%$ \\
\hline & & & $\Phi_{1,3}$ & $9 \%$ & & & $2,26 \%$ & $1,09 \%$ \\
\hline & & & & \multirow{3}{*}{\multicolumn{2}{|c|}{ Suma ryzyka dla }} & $\Phi_{1,1}$ & $24,28 \%$ & $9,66 \%$ \\
\hline & & & & & & $\Phi_{1,2}$ & $32,12 \%$ & $13,53 \%$ \\
\hline & & & & & & $\Phi_{1,3}$ & $15,04 \%$ & $9,1 \%$ \\
\hline
\end{tabular}

Źródto: opracowanie własne

W tabeli 4 przedstawiono zestawienie ryzyka utraty funkcjonalności rozpatrywanej IK w wyniku materializacji zagrożeń. Wartości ryzyka inherentnego i rezydualnego obliczono na podstawie wzoru (2). Natomiast sumę ryzyk dla funkcjonalności realizowanych przez rozpatrywaną IK obliczono, wykorzystując wzór (3) (Wiśniewski, 2019, s. 58-59):

$$
\begin{gathered}
R_{\alpha, \beta}=P_{\alpha, \beta} \cdot\left|\Delta \Phi_{\alpha, \gamma}\right| \cdot\left(U_{\alpha, \beta}-M_{\alpha, \beta}\right) \\
U_{\alpha, \beta}-M_{\alpha, \beta}=0 \text { dla } M_{\alpha, \beta} \geq U_{\alpha, \beta}
\end{gathered}
$$

gdzie:

$\alpha$ - indeks IK,

$\beta$ - indeks zagrożenia, $\gamma$ - indeks funkcjonalności rozpatrywanej IK,

$\mathrm{R}_{\alpha, \beta}$ - wartość ryzyka $<0 \%, 100 \%>$,

$\mathrm{P}_{\alpha, \beta}^{\alpha, \beta}$ - prawdopodobieństwo wystąpienia zagrożenia $\beta$ na skali $<0,1>$,

$\mathrm{U}_{\alpha, \beta}$ - podatność IK na zagrożenie $\beta$ na skali $\left.<0,1\right\rangle$, $\Delta \Phi_{\alpha, \gamma}$ - skutek materializacji zagrożenia $\beta<0 \%, 100 \%>$, $\mathrm{M}_{\alpha, \beta}^{\alpha, \gamma}$ - suma wpływu zabezpieczeń na podatność IK na zagrożenie $\beta$ na skali $<0,1>$

gdzie:

$\mathbf{R}_{\Phi_{\alpha, \gamma}}=\sum_{\alpha=1}^{n} \sum_{\beta=1}^{j} \frac{P_{\alpha, \beta}}{\sum_{\alpha=1}^{n} \sum_{\beta=1}^{j} P_{\alpha, \beta}} \cdot\left|\Delta \Phi_{\alpha, \gamma}\right| \cdot\left(U_{\alpha, \beta}-M_{\alpha, \beta}\right)$

$\mathrm{R}_{\Phi_{\alpha, \gamma}}$ - ryzyko dla rozpatrywanej funkcjonalności IK,

j - liczba zagrożeń, na które podatna jest IK o indeksie $\alpha$,

$\mathrm{n}$ - liczba rozpatrywanych IK. 
Przykładem problemu decyzyjnego, który wynika z sytuacji rozpatrywanych $I K$, jest niemal $10 \%$ ryzyko utraty funkcjonalności $\Phi_{1,1}$ - przerobu ropy naftowej oraz wytworzenia produktów i półproduktów ropopochodnych (tab. 4). Na ryzyko utraty funkcjonalności $\Phi_{1,1}$ składają się ryzyka związane $\mathrm{z}$ zagrożeniami: $\mathrm{Z}_{1,1}$ - pożarem $\left(\mathrm{R}_{\Phi 1,1}=1,75 \%\right), \mathrm{Z}_{1,2}-$ wybuchem $\left(\mathrm{R}_{\Phi 1,1}=\right.$ $7,39 \%)$ i $Z_{1,3}$ - skażeniem środowiska $\left(R_{\Phi 1,1}=0,53 \%\right) . \mathrm{Na}$ potrzeby przykładu obliczeniowego przyjęto, że celem operatora rafinerii PKN ORLEN S.A. jest utrzymanie funkcjonalności $\Phi_{1,1}$ powyżej progu bezpieczeństwa wynoszącego $90 \%$. Przyjmując $9,66 \%$ ryzyko utraty funkcjonalności $\Phi_{1,1}$, jej dostępność w wyniku materializacji zagrożeń $Z_{1,1}, Z_{1,2}$ i $Z_{1,3}$ jest prognozowana na $83,34 \% \mathrm{wg}$ wzoru (4) (Wiśniewski, 2019, s. 61):

$$
\Phi_{a, \gamma}\left(t_{n+1}\right)=\Phi_{a, \gamma}\left(t_{n}\right)-R_{\Phi_{a, \gamma}}\left(t_{n}\right)
$$

gdzie:

$\Phi_{a, \gamma}\left(t_{n+1}\right)$ - prognozowy poziom funkcjonalności $\mathrm{w}$ momencie $t_{n+1}$,

$\Phi_{a, y}\left(t_{n}\right)$ - zmierzony/oszacowany poziom funkcjonalności w momencie $t_{n}$,

$\mathbf{R}_{\Phi_{a, y}}\left(t_{n}\right)$ - wartość ryzyka utraty funkcjonalności w momencie $t_{n}$.

Przyjęty próg bezpieczeństwa oraz wartość ryzyka związana $\mathrm{z}$ zagrożeniami, na które podatna jest $\mathrm{IK} \mathrm{V}_{1}$, wskazują, że rozpatrywany problem decyzyjny ma trzy obszary decyzyjne wyznaczone przez zagrożenia $Z_{1,1}$, $Z_{1,2}$ i $Z_{1,3}$. Wykorzystując wzory (5) i (6) (Wiśniewski, 2019 , s. 73-74), wyznaczono odpowiednio względne istotności obszarów decyzyjnych i względne istotności decyzji elementarnych (rys. 2).

W celu ograniczenia ryzyka utraty funkcjonalności operator IK $\mathrm{V}_{1}$ może zastosować dodatkowe zabezpieczenia (decyzje elementarne) wykorzystywane m.in. w rafinerii LOTOS S.A. (LOTOS, 2018). Wśród wskazanych dodatkowych zabezpieczeń dostępnych dla operatora IK $\mathrm{V}_{1}$ nie wskazano par sprzecznych. Oznacza to, że wymienione zabezpieczenia mogą być stosowane $\mathrm{w}$ dowolnej konfiguracji:

$$
D_{\alpha, \beta}=\frac{R_{\alpha, \beta}}{\sum_{\beta=1}^{j} R_{\alpha, \beta}} \cdot 100
$$

gdzie:

$\mathrm{D}_{a, \beta}$ - względna istotność obszaru decyzyjnego związanego z zagrożeniem o indeksie $\beta$.

$$
\mathbf{d}_{\alpha, \beta, \lambda}=\frac{\mathbf{m}_{\alpha, \beta, \lambda}}{\sum_{\lambda=1}^{\mathbf{i}} \mathbf{m}_{\alpha, \beta, \lambda}}
$$

gdzie:

$\lambda$ - indeks zabezpieczenia,

$\mathrm{d}_{\alpha, \beta, \lambda}$ - względna istotność decyzji elementarnej związanej

$\mathrm{z}$ zagrożeniem o indeksie $\beta$, na które podatna jest IK

o indeksie $\alpha$,

$\mathrm{m}_{\alpha, \beta, \lambda}$ - wartość podniesienia odporności rozpatrywanej

IK o indeksie $\alpha$ na zagrożenie o indeksie $\beta$ w wyniku zastosowania zabezpieczenia o indeksie $\lambda$.

Ze względu na brak danych dotyczących skuteczności stosowanych zabezpieczeń ich wpływ na podatność IK $\mathrm{V}_{1}$ został oszacowany losowo na skali od 0 do 1 , gdzie 0 oznacza całkowity brak skuteczności zabezpieczenia, a 1 zapewnienie odporności na zagrożenie.

Wyniki rozwiązania problemu decyzyjnego metodą Analysis of Interconnected Decision Areas (Krupa, Ostrowska, 2012) ilustruje tabela 5. Analiza wyników ryzyka utraty funkcjonalności $\Phi_{1,1}$ oraz jej prognozowanej wartości wskazuje, że przy przyjętym celu utrzymania dostępności funkcjonalności na poziomie $90 \%$ operator rafinerii PKN ORLEN S.A. może zastosować dowolną kombinację rozpatrywanych zabezpieczeń. Każda z możliwych decyzji pozwala na utrzymanie dostępności funkcjonalności $\Phi_{1,1}$ w przedziale od 90,21\% (decyzja 8, 17 i 26) do 91,91\% (decyzja 1, 10 i 19).

Wprowadzenie nowych zabezpieczeń ustala nową sytuację rozpatrywanej IK (tab. 6). Dla zagrożenia $Z_{1,1}$ - pożaru wprowadzono zabezpieczenie $M_{1,1,3}$ - okładziny ognioodporne, dla zagrożenia $Z_{1,2}$ - wybuchu wprowadzono zabezpieczenie $M_{1,2,2}$ - system odprowadzający opary i gazy na pochodnię gazową, dla zagrożenia $Z_{1,3}$ - skażenia środowiska wprowadzono zabezpieczenie $M_{1,3,2}$ - monitoring parametrów technologicznych.

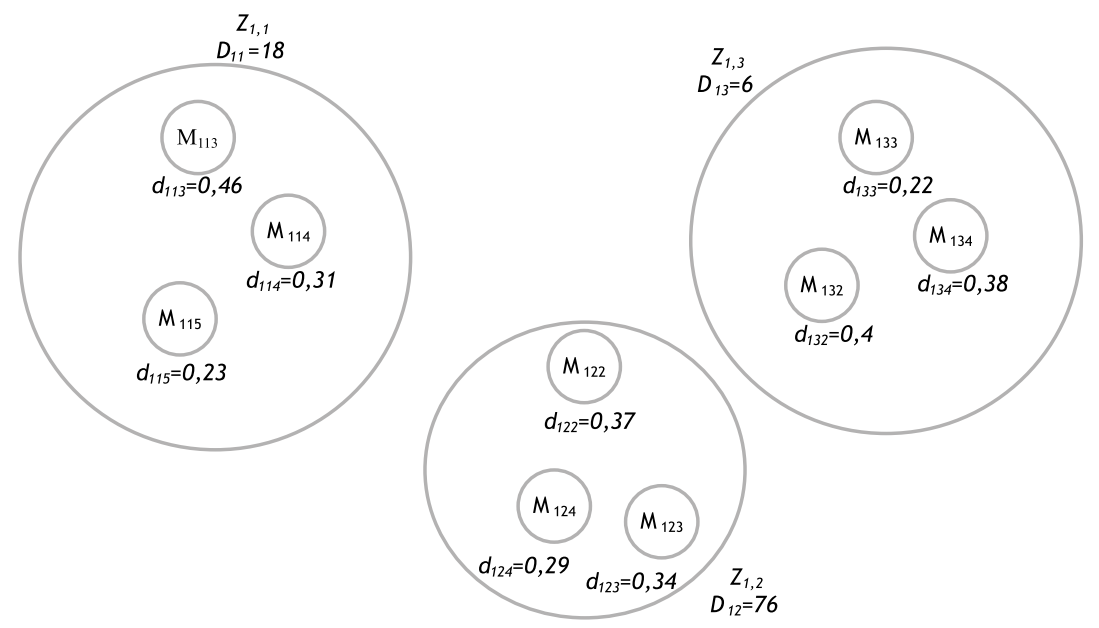

Rys. 2. Ilustracja rozpatrywanego problemu decyzyjnego dotyczącego IK $\mathrm{V}_{1}$ Źródto: opracowanie własne 


\section{2 | PRZEGLĄD ORGANIZACJI 11/2019}

Tabela 5. Wykaz decyzji realizujących cel operatora PKN ORLEN S.A.

\begin{tabular}{|c|c|c|c|}
\hline Decyzja & Ocena kosztowa & Wartość ryzyka utraty funkcjonalności $\Phi_{1,1}$ & Prognozowana wartość funkcjonalności $\Phi_{1,1}$ \\
\hline Decyzja 1 & 38,8 & $1,09 \%$ & $91,91 \%$ \\
\hline Decyzja 2 & 37,72 & $1,3 \%$ & $91,67 \%$ \\
\hline Decyzja 3 & 38,68 & $1,13 \%$ & $91,87 \%$ \\
\hline Decyzja 4 & 36,52 & $1,66 \%$ & $91,34 \%$ \\
\hline Decyzja 5 & 35,44 & $1,87 \%$ & $91,13 \%$ \\
\hline Decyzja 6 & 36,4 & $1,7 \%$ & $91,3 \%$ \\
\hline Decyzja 7 & 32,72 & $2,57 \%$ & $90,43 \%$ \\
\hline Decyzja 8 & 31,64 & $2,78 \%$ & $90,21 \%$ \\
\hline Decyzja 9 & 32,6 & $2,61 \%$ & $90,39 \%$ \\
\hline Decyzja 10 & 36,1 & $1,09 \%$ & $91,91 \%$ \\
\hline Decyzja 11 & 35,02 & $1,3 \%$ & $91,67 \%$ \\
\hline Decyzja 12 & 35,98 & $1,13 \%$ & $91,87 \%$ \\
\hline Decyzja 13 & 33,82 & $1,66 \%$ & $91,34 \%$ \\
\hline Decyzja 14 & 32,74 & $1,87 \%$ & $91,13 \%$ \\
\hline Decyzja 15 & 33,7 & $1,7 \%$ & $91,3 \%$ \\
\hline Decyzja 16 & 30,02 & $2,57 \%$ & $90,43 \%$ \\
\hline Decyzja 17 & 28,94 & $2,78 \%$ & $90,21 \%$ \\
\hline Decyzja 18 & 29,9 & $2,61 \%$ & $90,39 \%$ \\
\hline Decyzja 19 & 34,66 & $1,09 \%$ & $91,91 \%$ \\
\hline Decyzja 20 & 33,58 & $1,3 \%$ & $91,67 \%$ \\
\hline Decyzja 21 & 34,54 & $1,13 \%$ & $91,87 \%$ \\
\hline Decyzja 22 & 32,38 & $1,66 \%$ & $91,34 \%$ \\
\hline Decyzja 23 & 31,3 & $1,87 \%$ & $91,13 \%$ \\
\hline Decyzja 24 & 32,26 & $1,7 \%$ & $91,3 \%$ \\
\hline Decyzja 25 & 28,58 & $2,57 \%$ & $90,43 \%$ \\
\hline Decyzja 26 & 27,5 & $2,78 \%$ & $90,21 \%$ \\
\hline Decyzja 27 & 28,46 & $2,61 \%$ & $90,39 \%$ \\
\hline
\end{tabular}

Źródło: opracowanie własne

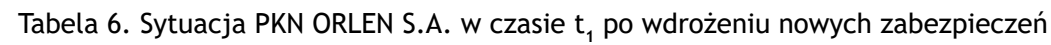

\begin{tabular}{|c|c|c|c|c|c|c|c|c|c|}
\hline \multirow{3}{*}{ IK } & \multicolumn{2}{|c|}{ Funkcjonalności } & \multicolumn{6}{|c|}{ Zagrożenia } & \multirow{3}{*}{$\begin{array}{l}\text { Podatność na } \\
\text { zagrożenie }\end{array}$} \\
\hline & \multirow[b]{2}{*}{ Symbol } & \multirow[b]{2}{*}{ Wartość } & \multirow[b]{2}{*}{ Symbol } & \multirow{2}{*}{$\begin{array}{l}\text { Wzbudzane } \\
\text { zagrożenie }\end{array}$} & \multirow{2}{*}{$\begin{array}{l}\text { Prawdopo- } \\
\text { dobieństwo }\end{array}$} & \multirow{2}{*}{$\begin{array}{l}\text { Ograniczenie } \\
\text { funkcjonal- } \\
\text { ności IK }\end{array}$} & \multicolumn{2}{|c|}{ Zabezpieczenia } & \\
\hline & & & & & & & Symbol & $\begin{array}{l}\text { Obniżenie } \\
\text { podatności }\end{array}$ & \\
\hline \multirow{7}{*}{$\mathrm{V}_{1}$} & \multirow{3}{*}{$\Phi_{1,1}$} & \multirow{3}{*}{$93 \%$} & \multirow{3}{*}{$Z_{1,1}$} & \multirow{3}{*}{$\begin{array}{l}\text { skażenia } \\
\text { środowiska, } \\
\text { wybuch }\end{array}$} & \multirow{3}{*}{0,7} & \multirow{3}{*}{$\begin{array}{l}-47 \%\left(\Phi_{1,1}\right) \\
-37 \%\left(\Phi_{1,2}\right) \\
-13 \%\left(\Phi_{1,3}\right)\end{array}$} & $M_{1,1,1}$ & 0,46 & \multirow{3}{*}{0,88} \\
\hline & & & & & & & $M_{1,1,2}$ & 0,31 & \\
\hline & & & & & & & $M_{1,1,3}$ & 0,71 & \\
\hline & \multirow[b]{2}{*}{$\Phi_{1,2}$} & \multirow[b]{2}{*}{$93 \%$} & \multirow[b]{2}{*}{$Z_{1,2}$} & \multirow[b]{2}{*}{ pożar } & \multirow[b]{2}{*}{0,56} & \multirow{2}{*}{$\begin{array}{l}-42 \%\left(\Phi_{1,1}\right) \\
-39 \%\left(\Phi_{1,2}\right) \\
-46 \%\left(\Phi_{1,3}\right)\end{array}$} & $\mathrm{M}_{1,2,1}$ & 0,16 & \multirow[b]{2}{*}{0,81} \\
\hline & & & & & & & $\mathrm{M}_{1,2,2}$ & 0,56 & \\
\hline & \multirow{2}{*}{$\Phi_{1,3}$} & \multirow{2}{*}{$93 \%$} & \multirow{2}{*}{$Z_{1,3}$} & \multirow{2}{*}{-} & \multirow{2}{*}{0,81} & \multirow{2}{*}{$\begin{array}{l}-9 \%\left(\Phi_{1,1}\right) \\
-9 \%\left(\Phi_{1,3}\right)\end{array}$} & $\mathrm{M}_{1,3,1}$ & 0,16 & \multirow{2}{*}{0,31} \\
\hline & & & & & & & $\mathrm{M}_{1,3,2}$ & 0,13 & \\
\hline
\end{tabular}

Źródło: opracowanie własne 


\section{Podsumowanie}

0 pracowana metodyka ZS-BIK wpisuje się w prowadzone prace badawcze dotyczące obszaru ochrony IK. Metodyka stanowi platformę pozwalającą na ich integrację oraz propozycję operacjonalizacji koncepcji wskazanych $\mathrm{w}$ pracach (Hofreiter, Zvakova, 2016; Häyhtiö, Zaerens, 2017).

Przeprowadzone badania wykazały, że metodyka ZS-BIK powinna być realizowana $\mathrm{w}$ siedmiu etapach: powołanie zespołu, określenie progów bezpieczeństwa, odwzorowanie charakterystyki IK, wygenerowanie scenariuszy zdarzeń niekorzystnych, sformułowanie problemu decyzyjnego, szacowanie ryzyka, wdrożenie zabezpieczeń. Elementem zapewniającym integralność etapów metodyki oraz umożlwiającym jej stosowanie przez operatorów IK reprezentujących dowolny system IK, jest model sytuacji IK. Określa on jej stan w obszarze zasobów składowych, realizowanych funkcjonalności, zagrożeń, stosowanych zabezpieczeń oraz powiązań występujących między zagrożeniami i IK.

Wykazano użyteczność metodyki ZS-BIK dla podmiotów odpowiedzialnych za ochronę IK. W przypadku polskich operatorów IK jest to m.in. wsparcie w obowiązku realizacji zadań wynikających z procesu planowania cywilnego, obejmującego następujące etapy:

- etap analizy jest wspomagany poprzez możliwość opisu rozpatrywanej IK według zaproponowanego standardu charakterystyki IK,

- etap opracowania planu jest wspomagany poprzez możliwość sformułowania problemu decyzyjnego, którego rozwiązanie dostarczy informacji, jakie zabezpieczenia zastosować w kontekście rozpoznanych zagrożeń, na które podatna jest IK,

- etap wdrożenia jest wspomagany poprzez możliwość pozyskania informacji o spodziewanym ryzyku i poziomie funkcjonalności IK po zastosowaniu nowych zabezpieczeń.

\section{dr inż. Michał Wiśniewski \\ Politechnika Warszawska \\ Wydział Zarządzania \\ ORCID: 0000-0003-3435-3114 \\ e-mail: Michal.Wisniewski@pw.edu.pl}

\section{Przypisy}

1) Próg bezpieczeństwa - poziom sprawności uznany przez operatora IK za wystarczający do realizacji zadań IK wynikających z zobowiązań wobec społeczeństwa.

2) Sytuacja kryzysowa - wpływająca negatywnie na poziom bezpieczeństwa ludzi, mienia w znacznych rozmiarach lub środowiska, wywołującą znaczne ograniczenia $\mathrm{w}$ działaniu włásiwych organów administracji publicznej ze względu na nieadekwatność posiadanych sił i środków (Dz.U. z 2019 r., poz. 1398. art. 3, pkt 1).

3) Wzbudzenie zagrożenia - zaistnienie sprzyjających warunków do materializacji zagrożenia.

4) Przepompownia ścieków, żeby odbierać nieczystości, potrzebuje dostaw prądu do zasilania pomp. Zerwanie sieci trakcyjnej powoduje brak zasilania pomp i utratę funkcjonalności przepompowni.

\section{Bibliografia}

[1] Bbk.bund.de (2011), Method of Risk Analysis for Civil Protection, https://www.bbk.bund.de/SharedDocs/Downloads/BBK/EN/ booklets_leaflets/Method_of_\%20Risk_Analysis.pdf?_blo$\mathrm{b}=$ publicationFile, access date: 02.05.2018.

[2] Bloomfield R., Popov P., Salako K., Stankovic V., Wright D. (2017), Preliminary Interdependency Analysis: An Approach to Support Critical Infrastructure Risk Assessment, „Reliability Engineering \& System Safety”, Vol. 167, pp. 198-217.

[3] Hatton T., Brown C., Kipp R., Seville E., Brouggy P., Loveday M. (2018), Developing Model and Instrument to Measure the Resilience of Critical Infrastructure Sector Organisations, „International Journal of Critical Infrastructures", Vol. 14, No. 1, pp. 59-79.

[4] FEMA (1997), Multi Hazard Identification and Risk Assessment, https://www.fema.gov/media-library/assets/documents/7251, access date: 02.07.2018.

[5] FEMA (2017), Sandy Five Years Later, http://fema.gov/sandy-5-year, access date: 28.03.2019.

[6] Häyhtiö M., Zaerens K. (2017), A Comprehensive Assessment Model for Critical Infrastructure Protection, „Management and Production Engineering", Vol. 8, No. 4, pp. 42-53.

[7] Hofreiter L., Zvakova Z. (2016), Theoretical Aspects of Critical Infrastructure Protection, [in:] A. Kravcov, E. Cherepetskaya, V. Pospichal (eds.), Durability of Critical Infrastructure, Monitoring and Testing, Springer, pp. 39-147.

[8] Johansen C., Tien I. (2018), Probabilistic Multi-scale Modeling of Interdependencies between Critical Infrastructure Systems for Resilience, „Sustainable and Resilient Infrastructure” Vol. 3, No. 1, pp. 1-15.

[9] Kosieradzka A., Zawiła-Niedźwiecki J. (red.), (2016), Zaawansowana metodyka oceny ryzyka w publicznym zarządzaniu kryzysowym, edu-Libri, Kraków-Legionowo.

[10] Krupa T., Ostrowska T. (2012), Decision - Making in Flat and Hierarchical Decision Problems, „Foundations of Management”, Vol. 4, No. 2, pp. 23-36

[11] Lidwa W. (2015), Zarządzanie kryzysowe, AON, Warszawa.

[12] LOTOS (2018), Informacja o występujacych zagrożeniach, http://m.odpowiedzialny.lotos.pl/repository/39634/, data dostępu: 04.04.2018 r.

[13] Mem.ie (2010), A Guide to Risk Assessment In Major Emergency Management, http://mem.ie/wp-content/uploads/2015/05/A-Guide-to-Risk-Assessment.pdf, access date: 06.06.2018.

[14] Msb.se (2012), Swedish National Risk Assessment 2012, https://www.msb.se/RibData/Filer/pdf/26621.pdf, access date: 09.06.2019.

[15] Pescaroli G., Kelman I. (2017). How CI Orients International Relief in Cascading Disasters, „Journal of Contingencies and Crisis Management", Vol. 25, No. 2, pp. 56-67.

[16] PN-ISO 31000:2012 Zarzadzanie ryzykiem - zasady i wytyczne, PKN (2012), https://sklep.pkn.pl/pn-iso-31000-2012p.html, data dostępu: 28.07.2017 r.

[17] Powiat-plock.pl (2015), Plan Zarzadzania Kryzysowego, http://powiat-plock.pl/attachments/article/44/, data dostępu: 28.12.2017 r.

[18] Preventionweb.net (2009), Working with Scenarios, Risk Assessment and Capabilities in the National Safty and Security Strategy of Netherland, https://www.preventionweb.net/files/26422_guidancemethodologynationalsafetyan.pdf, access date: 07.06.2018. 
[19] Publicsafety.gc.ca (2013), All Hazards Risk Assessment Methodology Guidelines, https://www.publicsafety.gc.ca/cnt/ mrgnc-mngmnt/mrgnc-prprdnss/ll-hzrds-rsk-ssssmnt-en. aspx, access date: 15.05.2018.

[20] Pursiainen C. (2018), Critical Infrastructure Resilience: A Nordic Model in the making? „International Journal of Disaster Risk Reduction", Vol. 27, pp. 632-641.

[21] Szołtysek J. 2(014), Przesłanki i założenia koncepcji logistyki społecznej, „Gospodarka Materiałowa i Logistyka”, Nr 2, s. 2-7.

[22] Ustawa z 26 kwietnia, 2007 r. o zarządzaniu kryzysowym (Dz.U. z 2019 r., poz. 1398).

[23] Wiśniewski M. (2019), Zarządzanie sytuacyjne bezpieczeństwem infrastruktury krytycznej, Politechnika Warszawska, Warszawa.

[24] Wiśniewski M., Ostrowska T. (2016), Wyzwania i dobre praktyki zarządzania bezpieczeństwem infrastruktury krytycznej, [w:] M. Ćwiklicki, M. Jabłoński, S. Mazur, Współczesne koncepcje zarzadzania publicznego. Wyzwania modernizacyjne sektora publicznego, Fundacja GAP, Kraków, s. 111-125.

\section{Methodology of Situational Management of Critical Infrastructure Safety}

\section{Summary}

The article presents the methodology of Situational Management Safety of Critical Infrastructure (CI), which allows for mapping the current characteristics of $\mathrm{CI}$ in the areas of resources, functionality, threats, precautions and all the connections of the investigated CI with other objects of this type. Based on the Model of CI Situation, the Methodology of Situational Management Safety of Critical Infrastructure allows for: generating threats development scenarios, formulating a decision problem, with a set of precautions as a solution applied to identified threats, to which CI is vulnerable, and risk level estimation and precautions implementation.

\section{Keywords}

critical infrastructure, situation model, decision problem, risk assessment 